\title{
Common Loon, Gavia immer, Nest Attendance Patterns Recorded by Remote Video Camera
}

\author{
Wing Goodale, Lee AtTiX, and David Evers \\ BioDiversity Research Institute, 19 Flaggy Meadow Road, Gorham, Maine 04038 USA
}

Goodale, Wing, Lee Attix, and David Evers. 2005. Common Loon, Gavia immer, nest attendance patterns recorded by remote video camera. Canadian Field-Naturalist 119(3): 455-456.

We recorded the complete day/night nesting attendance of a Common Loon (Gavia immer) pair using a remote video camera. We found that the male and female share incubation duty equally, but that the female incubates primarily at night (95.8\%) when the male defends the territory.

Key Words: Common Loon, Gavia immer, incubation pattern, sex, day, night, remote camera, Maine.

Researchers in the past have been limited to diurnal observations of Common Loon (Gavia immer) nesting behavior. Whereas many of those studies were conducted on unmarked loons (Sjolander and Agren 1972; Taylor 1974; McIntyre 1975), making the role of sex in incubation difficult to study, recent capture and marking techniques by Evers $(1994,2001)$ now allow researchers to determine the sex of the incubating birds. Past studies of nest attendance with marked birds have shown possible relationships between time of day and sex of the incubating bird. Paruk (2000) found that 23\% of the time there was a least one nest switch during the night, suggesting nest exchanges may be "optimized" for males to patrol the territory at night. Gostomski and Evers (1998) found that males incubated twice as often in the evening and the females twice as often in the morning, indicating the pair switches incubation duty after sunset. Evers (1994) found no significant sex difference in incubation effort during daylight hours. Our study explored parental incubation patterns by using a remote video camera to record both day and night nest attendance of a marked Common Loon pair.

In 2001 the Common Loon pair on Coleman Pond,

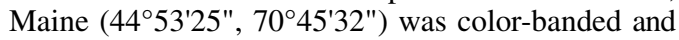
sexed (through morphometric measurements) using body mass as the primary criterion (Evers 2004*). On April 2003 we set up a remote video camera equipped with a standard lens as well as a infrared lens and light for night vision (supplied by SeeMore Wildlife Systems) at a traditional nesting island in Coleman Pond, which is a single loon-territory lake. The camera, powered by solar panels, sent live images to a base computer and time-lapse VCR. At dusk the infrared light and lens would automatically turn on, allowing a recording of the entire incubation period. We then reviewed the time-lapse tapes and recorded (into a Microsoft Excel spreadsheet) the sex of the incubating bird (using the color bands) and the time of each nest exchange, as well as the amount of time the nest was left unattended. Events were not recorded after the eggs began pipping. Exact sunrise and sunset times for the lake were obtained from U.S. Navy records. From these data we calculated the precise time the male and female were on the nest during the day and night.
TABLE 1. Total hours and minutes of nest attendance by time of day and sex (percentage is in parentheses).

\begin{tabular}{lrrcc}
\hline \hline & Empty & Female & Male & Total \\
\hline Day & $30: 30(7.5)$ & $97: 08(23.8)$ & $280: 58(68.8)$ & $408: 36$ \\
Night & $0: 55(0.5)$ & $193: 39(95.8)$ & $7: 33(3.7)$ & $202: 07$ \\
Total & $31: 25(5.1)$ & $290: 47(47.6)$ & $288: 31(47.2)$ & $610: 43$ \\
\hline \hline
\end{tabular}

Our results demonstrated that male and female loons shared incubation duty equally (Table 1). However, the female incubated the eggs primarily at night, whereas the male incubated primarily during the day. Gostomski and Evers (1998) interpreted that the male/female dusk and dawn nest attendance pattern indicated that the male defended the territory at night. That observation confirmed findings by McIntyre (1988), who suggested that during incubation males patrol the territory at night. Our results support those findings, and qualitative observations of the Coleman Pond loon pair indicated the male actively defended the territory at night from intruder loons with frequent yodel calls while the female was incubating.

\section{Acknowledgments}

We especially thank the MBNA Foundation, whose financial support made this project possible. In addition, Whitney and Tony Oppersdorff deserve special thanks for their generousity in providing a base station for the research equipment. Michelle Gharst also deserves special recognition for her review of the tapes.

Document Cited (marked $*$ in text)

Evers, D. C. 2004. Status assessment and conservation plan for the Common Loon (Gavia immer) in North America: Final Draft. U.S. Fish and Wildlife Service, Hadley, Massachusetts.

\section{Literature Cited}

Evers, D. C. 1994. Activity budget of marked Common Loon (Gavia immer) nesting population. Hydrobiologia 279/280: 415-420.

Evers, D. C. 2001. Capture and color-marking Common Loons: an evaluation of potential impacts. Pages 2-26 in Common Loon population studies: continental mercury 
patterns and breeding territory philopatry. Ph.D. dissertation, University of Minnesota, St. Paul.

Gostomski, T. J., and D. C. Evers. 1998. Time-activity budget for Common Loon, Gavia immer, nesting on Lake Superior. Canadian Field-Naturalist 112: 191-197.

McIntyre, J. W. 1975. Biology and behavior of the Common Loon (Gavia immer) with reference to its adaptability in the man-altered environment. Ph.D. dissertation, University of Minnesota, Minneapolis.

McIntyre, J. W. 1988. The Common Loon: Spirit of northern lakes. University of Minnesota Press, Minneapolis, Minnesota. 288 pages.
Paruk, J. D. 2000. Incubating roles and patterns in Common Loons (Gavia immer). Pages 50-54 in Loons: Old history and new findings. Edited by J. W. McIntyre and D. C. Evers. Proceedings of a Symposium from the 1997 meeting, American Ornithologists' Union. North American Loon Fund, Holderness, New Hampshire.

Sjolander, S., and G. Agren. 1972. Reproductive behavior of the Common Loon. Wilson Bulletin 84: 296-308.

Taylor, K. 1974. The loon. Adirondack Life 5: 30-37.

Received 8 November 2004

Accepted 30 August 2005 